\section{Virgo's vacuum failure stalls gravity-wave hunt}

The Virgo gravity-wave interferometer, an €80-million (US\$114-million) experiment located near Pisa, Italy, has been incapacitated by a vacuum failure for most of the summer and is expected to stay out of commission for another few months.

During a test on 9 May a glass viewport in the L-shaped detector shattered, sending shards of glass into one of the laser-reflecting mirrors and its ancillary instrumentation. The mirror was damaged beyond repair and is being replaced.

The team has decided to replace all 100 viewports to avoid another failure. Francesco Fidecaro, Virgo's spokesman, who is a physicist at the University of Pisa, says the original viewports might not have been "appropriate" for the operating conditions. Physicists believe that it was not the vacuum itself but the vibrations created by the pumps that caused the port to fail. They are confident that the new viewports will not fail in the same way.

For a longer version of this story, see http://tinyurl. com/5dfzug

\section{Fossil hunter accused of stealing dinosaur}

A high-profile fossil collector from Montana will go to court on 23 September for allegedly stealing a US $\$ 400,000$ raptor specimen from private land.

Nate Murphy, a former curator of palaeontology at the Phillips County Museum in Malta, was charged last week with the theft of a fox-sized raptor, nicknamed 'Sid Vicious', from the 77-million-year-old Judith River Formation. State and federal agents began a probe in spring 2007 after authorities heard of a possible misappropriation from participants in Murphy's collecting business, the Judith River Dinosaur Institute, now in Billings, Montana.

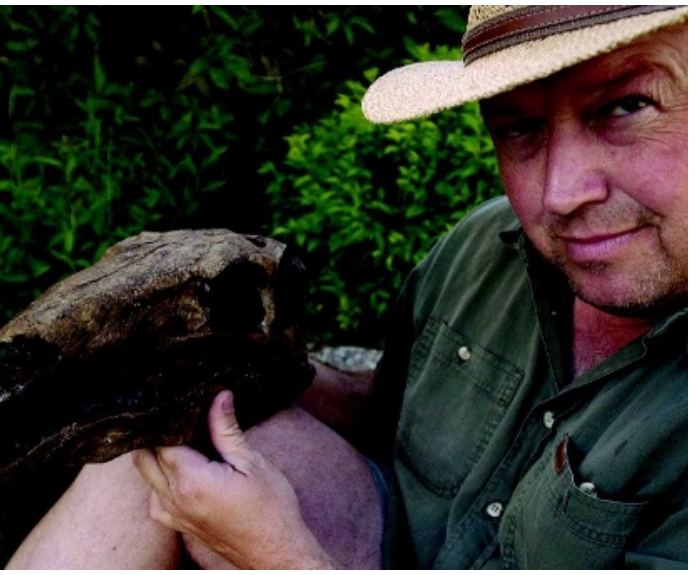

Dinosaur collector Nate Murphy.

Bisphenol A exposure may pose disease risk

High levels of bisphenol $A$, a chemical found in some food and drinks containers, may be associated with an increased risk of cardiovascula disease and diabetes

An epidemiological analysis of 1,455 adults in the United States, published this week (I. A. Lang et al. J. Am. Med. Assoc. 300, 1303-1310; 2008), is the first to find a link between bisphenol $A$ and disease in humans. The results are likely to fuel further debate over whether the chemical should be banned, but the authors caution that the study must first be replicated. Earlier this year, the US National Toxicology Program expressed "some concern" about the possible impact of the compound on fetuses, infants and children.

In a draft report released in August, the US Food and Drug Administration stated that "food contact" products contain bisphenol $A$ are safe. The agency has said it will continue to review the compound as more data become available.

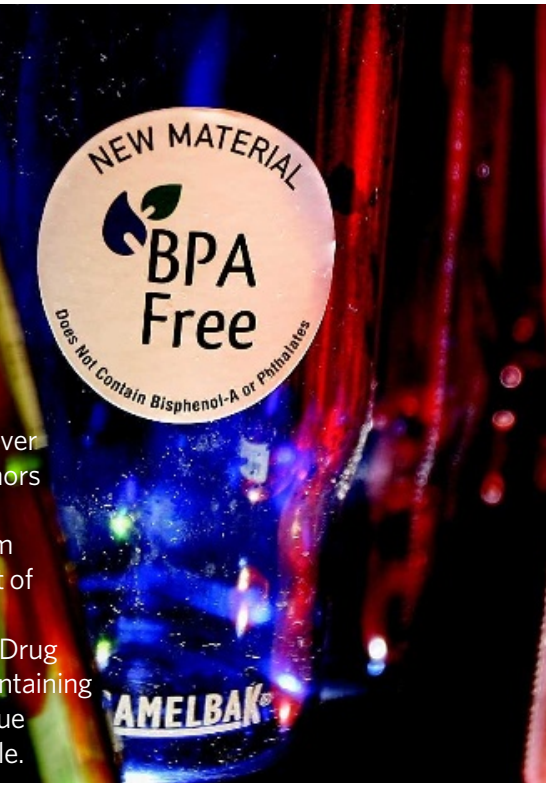

On 14 September, Murphy and another dinosaur he helped to collect - 'Leonardo', a mummified hadrosaur with skin and organs - were featured in a Discovery Channel film on US television.

\section{Blandford to lead next decadal astronomy survey}

The US National Academies have appointed Roger Blandford to chair the next decadal survey in astronomy, starting a two-year process that culminates in a priority list of astronomy projects for the next ten years (see Nature 443, 386-389; 2006).

Blandford, director of the Kavli Institute for Particle Astrophysics and Cosmology at Stanford University in California, will assemble a committee of about 20 people. They will gather input from hundreds of panel members into a final report and wish-list, expected by mid-2010. NASA, the National Science Foundation and Congress often cite the report in setting science budgets.

But the last survey, in 2001, was overambitious in recommending seven major projects. Cost overruns mean that none of them will be finished this decade. That survey's highest priority, the $\$ 4.5$-billion James Webb Space Telescope, is due for launch in 2013.

For a longer version of this story, see http://tinyurl. com/6hebqn

\section{US health agency gets creative with grants}

The National Institutes of Health (NIH) plans to spend more than $\$ 250$ million over the next five years to inject a mega-dose of creativity into its basic grants.

Beginning with funding of \$25 million in 2009, conventional R01 grants will be supplemented by 'transformational' awards, or T-R01s. The agency will test new peerreview approaches to pick out "bold and groundbreaking" proposals that "reflect an exceptional level of creativity" and may "promote radical changes" in a field, the NIH said last week.

Investigators working in any NIH-funded discipline can apply for the grants. The agency says that areas of creative need include the science of behaviour change; protein capture; functional variation in mitochondria; complex three-dimensional tissue models; and pharmacogenomics.

\section{Court fines entomologists for illegal collecting in India}

The case of two Czech entomologists arrested in India took a further turn last week when a court in Darjeeling sentenced Emil Kučera to three years in prison, plus a 60,000-rupee (US\$1,300) fine, under the country's Wildlife Act and Biological Diversity Act. His colleague, Petr Švácha of the Institute of Entomology of the Academy of Sciences of the Czech Republic in Cěské Budějovice, was fined 20,000 rupees.

The pair have been held in India since 22 June for collecting butterflies from a national park without a permit. Kučera has been given bail and plans to appeal; Švácha is staying in India to help Kučera’s legal fight.

"This case points to the need for revision of India's conservation legislation," says Priyadarsanan Dharma Rajan, a taxonomist with the Ashoka Trust for Research in Ecology and the Environment in Bangalore. "There are no cases of any insect gone extinct due to collection. Threats to insects come from pesticides poured into our fields and habitat loss due to land-use changes." 